\title{
Human Capital, HRM Practices and Organizational Performance in Pakistani Construction Organizations: The Mediating Role of Innovation
}

\author{
Huma Sarwar \\ COMSATS Institute of Information Technology, Islamabad, Pakistan \\ Bilal Khan \\ COMSATS Institute of Information Technology, Islamabad, Pakistan \\ Kashif Nadeem \\ National University of Modern Languages, Islamabad, Pakistan \\ Junaid Aftab \\ COMSATS Institute of Information Technology, Islamabad, Pakistan
}

\begin{abstract}
Human capital and human resource management practices play a vital role in success of any organization. When employees feel satisfy with human resource policies of an organization they give their best to increase the organizational performance. Construction industry provides job opportunities to large number of people in all over the world.In Pakistan, construction industry is making progress with rapid rate. To investigate the importance of human resources in organizational performance, a research was carried out to check the influence of human capital and human resource management practices on organizational performance with the mediating role of innovation in construction industry of Pakistan. The data for this study was collected from the 315 employees from construction companies of Pakistan through structured questionnaires using simple random sampling. Data analysis technique like structural equation modeling was applied using SPSS AMOS. The findings indicated that human capital and human resource management practices are positively associated with organizational performance. Also, innovation mediates the relationship between independent variables (human capital \& HRM practices) and organizational performance in construction industry of Pakistan.
\end{abstract}

Keywords: Human resource management, Organizational performance, Innovation, Construction industry

\section{INTRODUCTION}

In this dynamic and competitive environment, organizations are in need of investing and supporting their human capital to remain and sustain in competitive advantage. Now-a-days, organizations are facing aggressive and productive environment. The success of these organizations is heavily depending on their capacity and ability to adapt their structures able to face the competition and maintain positive relations with their surroundings. This is especially for the construction organizations where worker's cost and productivity are the main elements of gross profit. 
Buller and McEvoy (2012) stated that in these days human capital is considered as critical success factors for every organizations' development and for running smooth business. HRM is related to the managing organization's workers includes training and development, planning, performance measurement career development, staffing, compensation and benefits, leaving the organizations. So, HRM in construction organizations is a complex and manifold activity that concerns with the application of ideas.

However, its significance in the construction environment is still undefined. On the one hand, many literaturesand studies have identified HRM as amajor factor towards organizational performance (Barczak\& Wilemon, 1992; Tampoe\& Thurloway, 1993). Investmentin HRM improves the quality of human capital, results the high productivity that in turn high profitability. This study aims to evaluate the role of HRM in construction organizations in the economy of Pakistan with the linkage of innovation. The role of human capital on organizational performance is not clear. Thus, the efforts of the study are used to investigate the impact of human capital of organizational performance with the mediating effect of innovation.

\section{OBJECTIVES}

1. To investigate the association between HRM practices and organizational performance.

2. To identify the dimensions of human capital and their magnitude on the organizational performance.

3. To analyze the mediating impact of innovation on human capital and HRM practices to organizational performance.

\section{LITERATURE REVIEW}

\section{HRM practices and organizational performance}

In the competitive and knowledge based economy, HR practicesaresupposed to be the most important resource. Now-a-days, it has become more crucial for organizational success (Moyeen\&Huq, 2001; Werther\& Davis, 1996).In today's competitive world, success of the organizations depends on the techniques management are utilizing thecapabilities, competencies and skills of their human resources (Absar\&Mahmood, 2011).

The impact of HRM practices on firm level has become important element.Many studies have analyzed and expressed a significant association between firm's performance and HRM practiceslike factors included in the HRM practices and performance of firms as turnover of employees, productivity, quality in sales, earning profits, market value and return on investment. (Lau \& May, 1998; Harel\&Tzafrir, 1999; Youndtet al., 1996; Khatri, 2000). Beer et al.(1984) suggested that there are some variables like employees' commitment, competence, cost effectiveness and congruence and cost effectiveness which performed their roles as intermediary variables. The new development of high innovation, communication, technology and information have proposed many construction organizations to effectively look for new thoughts, ideas for products or services, doing experiments for innovation, and bringing creative solutions for the purpose of bringing the betterment in the performance or quality of products, services, systems, and technology which are known as organizational innovation.

\section{Human capital attributes and organizational performance}

Researchers from different contexts found the significance of human capital for desired performance and outcomes like development, job creation, innovation, and economicdevelopment (Frese, 2000; Autio, 2005). Human capital attributes, such as skills of workers, training, trust, knowledge, education and have long been taken as critical success factors in organizational performance (Florin et al., 2003).A particular area for analysis,getting 
growing attention now-a-days by many practitioners and analysts, is the importance of human capital and its impact on organizational performance(Moyeen\&Huq, 2001).Ishikawa and Ryan (2002) suggested that it is the human capital that can enhance the firm performance. Moreover, academics and researchers observed that attributes of human capital play larger role in the firm performance by implementing some specific activities which are required for the knowledge creation in the working environment (Honig, 2001; Bosmaet al., 2004).

\section{Human capital, innovation and performance}

Today, competitive environment is getting dynamic, stiff and tougher by local and global competition, limited organizational resources and due to the technological change.So it is necessary for the organizations to adopt innovative ideas to be in competitive advantage (Holmqvist, 2004). Previous literatures include a limited number of studies examined the relationship between the human capital and performance but not explains the value of innovation (Camisón\&Villar-López, 2014).

Innovation is considered as a major factor for economic growth in developing countries (Lee \& Kang, 2007; Robson et al., 2009; Crespi\& Zuniga, 2011). It becomes critical to understand role of innovation at the firm level.Many Studies highlighted the importance of human capital among other factors as a driving force for innovation in context of performance (Dakhli\& De Clercq, 2004). The author of this study wants to put some efforts on determining the need of human capital for introducing innovations in the organizations because it has been observed that it helped in creating new knowledge. (Smith et al., 2005).

Hence, human capital when adopting the innovative ideas, products and processes is now becoming the main factor for organizational performance and productivity.

\section{Hypotheses}

H1: HRM practices are positively related to the organizational performance.

H2: Human capital is positively associated with organizational performance.

H3: Innovation mediates the relationship of HRM practices and organizational performance.

H4: Innovation mediates the relationship of Human capital and organizational performance.

$\mathrm{H}_{1}$

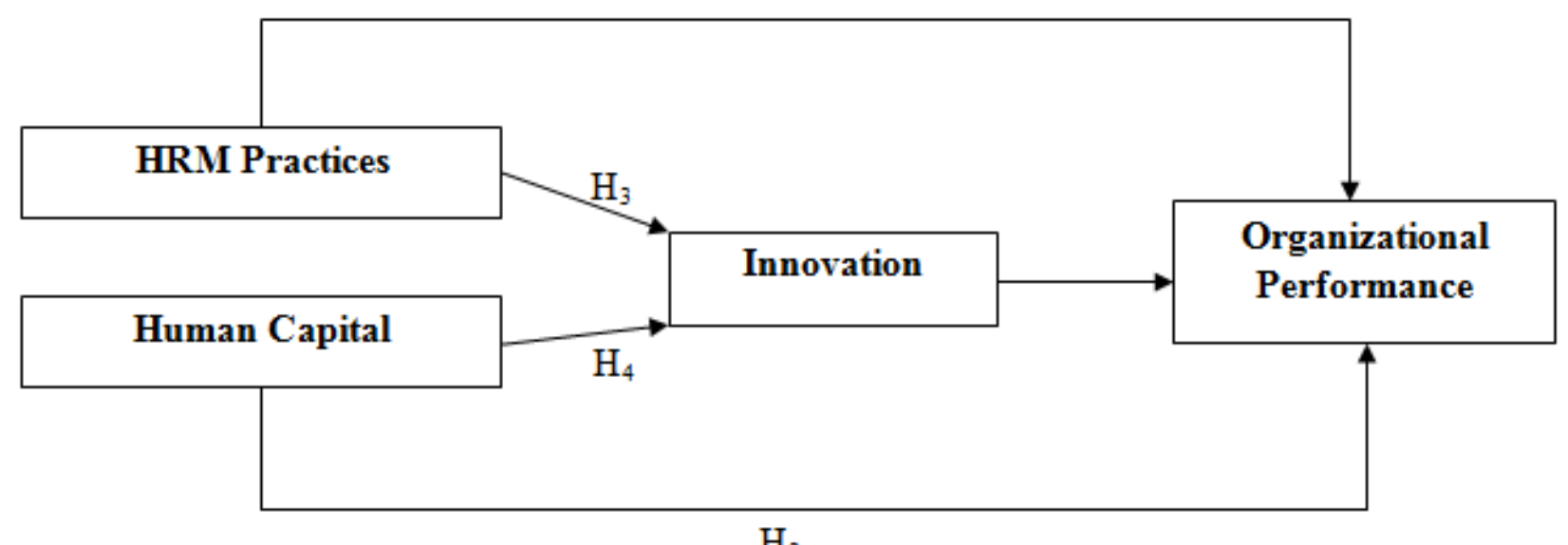

Figure 1: Research Model

\section{METHODOLOGY}

The study was conducted to explore the relationship among HRM practices, human capital, innovation and organizational performance. A pre-structured questionnaire was used to collect 
data to analyze the association among these variables. The data collected for this research was based on individual level. Concerning the survey, a questionnaire was developed with the aim of measuring HRM practices, Human capital, innovation and organizational performance. It is observed that for the data collection, survey is considered an easier approach (Yu \&Egri, 2005). The number of questionnaires distributed among the employees of construction industry were 470 of Pakistan using a simple random sampling technique. Out of 470 employees, 315 completed questionnaires were returned. For the analysis of data Software like SPSS using AMOS was used.

\section{POPULATION}

The population for present study is the employees of construction industry of Pakistan. The sample technique for this study is simple random sampling technique.

\section{Scale}

For human capital, the questionnaire items have three dimensions: training, trust and education. These items of the human capital were taken from previous literature on human capital (Delaney \&Huselid, 1996). HRM practices consisted of 8 Items adopted from Huselid (1995), the endogenous construct or dependent variable"organizational performance" consisted of 5 items. These items of dependent variable were adopted fromSchuler and Jackson (2005). The questionnaire items of "innovation" consisted of 10 items derived from Lin (2001).5 point likert scale has been used for this study to obtain the responses from participants in all scales. 1(Strongly Disagree) to 5 (Strongly Agree).

\section{Descriptive Statistics}

Table 1 shows the gender, age, education distribution of the current study.The total of 315 questionnaires wasreceived out of which 200 were males and 115 were females. The percentage of males of total respondents was 63.5 percent while the female percentage was only 36.5 percent. According to the age distribution, the respondents ranging from 20 to 30 were 75 (23.8\%), from 31 to 40 respondents were 135 (42.9\%), from 41 to 50 they were 70 $(22.2 \%)$ and from 51 to 60 the total respondents were 35(11.1\%).

The respondents having education of bachelor were 25 and its percentage was 7.9\%. The master degree holder respondents were $50.8 \%$ which is the greater number of this study. The respondents participated in the answering questionnaires having MS/M Phil degrees were $38.1 \%$. In the last the respondents who had PhD degrees were 10 and its percentage was 3.2 of total respondents.

Table 1: Demographic Information $(\mathrm{N}=315)$

\begin{tabular}{lcc}
\hline Variables & Frequency & Percentage \% \\
\hline Gender & 200 & \\
Male & 115 & 63.5 \\
Female & & 36.5 \\
Education Level & 25 & \\
Bachelors & 160 & 7.9 \\
Masters & 120 & 50.8 \\
MS/MPHIL & 10 & 38.1 \\
PhD & & 3.2 \\
Age Group & 75 & 23.8 \\
$21-30$ & & \\
\hline
\end{tabular}




\begin{tabular}{lcc}
\hline $31-40$ & 135 & 42.9 \\
$41-50$ & 70 & 22.2 \\
$51-60$ & 35 & 11.1 \\
\hline
\end{tabular}

\section{Reliability}

For testing the reliability of questionnaire for this study Cronbach's alpha test was utilized. The value of cronbach's alpha is greater than .07 which is considered as the acceptable value for internal consistency.

Table 2: Cronbach's Alpha

\begin{tabular}{lcc}
\hline Variables & Items & Cronbach's $\boldsymbol{\alpha}$ \\
\hline HRM Practices & 8 & 0.843 \\
Human Capital & 5 & 0.720 \\
Innovation & 10 & 0.732 \\
Organizational Performance & 5 & 0.854 \\
\hline
\end{tabular}

The cronbach's alpha of human capital, HRM practices, innovation and organizational performance is $0.720,0.843,0.732$ and 0.854 respectively, showed good scale reliability.

\section{Correlations}

The means and standard deviations and correlations of independent, dependent and mediating variables are presented in Table 3. Human capital has significant positive correlation with organizational performance $(r=0.693, p<0.01)$, HRM practices $(r=0.784, p<0.01)$. Innovation also has significant positive relationship with organizational performance $(r=0.743, p<0.01)$ which also justifies claim of the study andprovides confidence for testing Hypothesis. It is worth mentioning that the HRM practices and innovation are highly correlated with organizational performance, whereas Human capital was although positively correlated but having weak relationship than HRM practices and innovation.

Table 3: Correlations

\begin{tabular}{lcccccc}
\hline Variables & Mean & STD & ORG & HRM & HC & INN \\
\hline Org Performance & 3.68 & 0.94 & 1.000 & & & \\
HRM Practices & 3.59 & 0.65 & $.784^{* *}$ & 1.000 & & \\
Human Capital & 3.93 & 0.67 & $.693^{*}$ & $.775^{* *}$ & 1.000 & \\
Innovation & 3.47 & 0.73 & $.743^{* *}$ & $.676^{* *}$ & $.710^{* *}$ & 1.000 \\
\hline
\end{tabular}

ORG=organizational performance, $\mathrm{HRM}=\mathrm{HRM}$ practices, $\mathrm{HC}=$ human capital, $\mathrm{INN}=$ innovation **. Correlation is significant at the 0.01 level (2-tailed).

\section{Confirmatory Factor Analysis (CFA)}

The main aim of current study is to investigate the findings of previousresearchers and support our hypothesis. In order to analyze the given hypothesis, CFA and then hypothesis testing has been conducted (Hairet al., 2014). The initial value of these 28Items through CFA indicated a poor fit model because these values of factor loading were beyond the recommended levels.

Table 4: Model Fitness Ratio of CFA

\begin{tabular}{llllll}
\hline CMIN & CMIN/DF & GFI & NFI & CFI & RMSEA \\
\hline Model A & 1.782 & .732 & .764 & .768 & .068 \\
\hline
\end{tabular}


In the analysis, the modification indices showed ways to improve the fit. After deleting the items and modification indices the CFA expressed that a model is good fit. The values of CMIN/DF, NFI, IFI, TLI, CFI and RMSEA also improved that showed is table 5.

Table 5: Overall Measurement Model

\begin{tabular}{lcc}
\hline Fit Indices & Initial & Final \\
\hline CMIN/DF & 1.782 & 2.032 \\
CMIN & 789.04 & 149.582 \\
IFI & .779 & .928 \\
GFI & .732 & .918 \\
CFI & .768 & .932 \\
NFI & .764 & .932 \\
RMSEA & .068 & .048 \\
\hline
\end{tabular}

The $\chi 2$ value is 2.032 which areconsidered as the reasonable value for model fit and below the cutoff value of 5.0. RMSEA's value in the above table shows that it is 0.048 which is below from 0.05. Furthermore, CFA also presented that the model is good fitted. Findings confirmed that the model is good with the standards of the statistically fitness of model.

\section{Structural equation modeling}

Figure 2 represents that hypothesis were tested through SEM. From the analysis of the data, it was found that HRM practices $(\beta=0.618, p<0.01)$ was positively related to organizational performance. So results expressed that there is significant positive linkage among the performance of the organizations and practices of HRM. Thus, H1 was supported. Human capital $(\beta=0.214, p<0.01)$ was also positively associated with organizational performance. So, the current study supports the hypothesis 2 . Next, the author analyzed the role of innovation as a mediating effect with the rest of variables which are understudy in this research. In this study bootstrapping technique was used for testing the mediating impact of innovation on the HRM practices, human capital and on the performance of organization and the results also indicated that innovation mediates the connection among the performance of the organization and practices of HRM. HRM practices effect organizational performance significantly both directly $(\beta=0.61, p<0.01)$ and indirectly $(\beta=0.49, p<0.01)$ and $(\beta=0.38, p<0.01)$. It predicted the partial mediation of innovation with HRM practices and organizational performance. In the final hypothesis 4 , we predicted that innovation (the mediating variable) partially mediated the association between human capital and organizational performance. Human capital effects organizational performance significantly both directly $(\beta=.21, \mathrm{p}$-value $<0.01)$ and indirectly $(\beta$ $=.13$, p-value $<0.01)$ and $(\beta=0.38, \mathrm{p}<0.01)$., So it is proved that H3 is also accepted and partial mediation is found between these two variables. Hence, current study supports these hypothesis and partial mediation of innovation was found between the independent and dependent variables. 


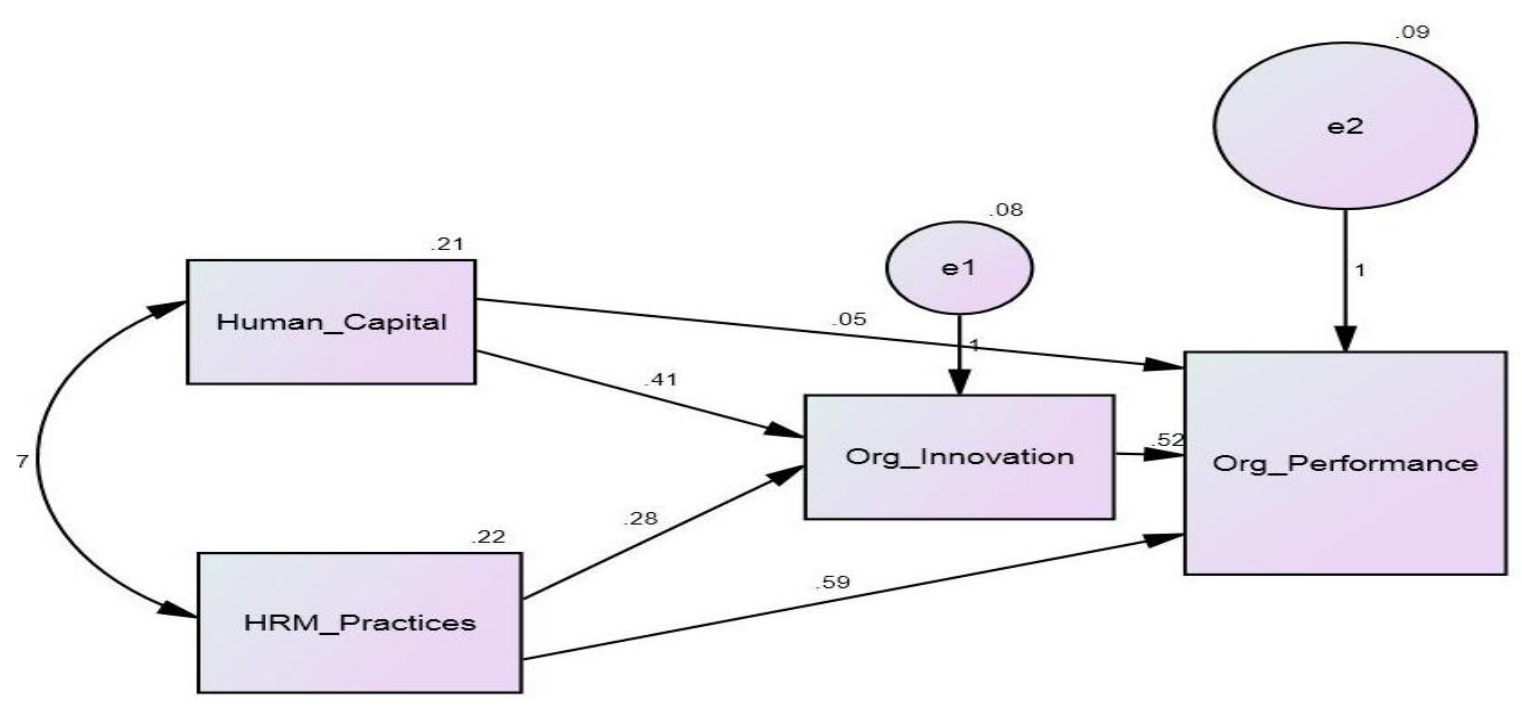

Table 6: Decision of Hypotheses

\begin{tabular}{|c|c|c|c|c|c|}
\hline Hypothesis & $\begin{array}{c}\text { Independent } \\
\text { Variable }\end{array}$ & $\begin{array}{c}\text { Mediating } \\
\text { Variable }\end{array}$ & $\begin{array}{l}\text { Dependent } \\
\text { Variable }\end{array}$ & $\begin{array}{c}\text { Regression } \\
\text { Coefficient }\end{array}$ & Decision \\
\hline H1 & $\begin{array}{c}\text { HRM } \\
\text { Practices }\end{array}$ & 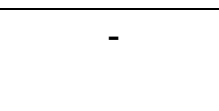 & $\begin{array}{l}\text { Organizational } \\
\text { Performance }\end{array}$ & 0.618 & Accepted \\
\hline $\mathrm{H} 2$ & $\begin{array}{l}\text { Human } \\
\text { Capital }\end{array}$ & - & $\begin{array}{l}\text { Organizational } \\
\text { Performance }\end{array}$ & 0.214 & Accepted \\
\hline $\mathrm{H} 3$ & $\begin{array}{c}\text { HRM } \\
\text { Practices }\end{array}$ & Innovation & $\begin{array}{c}\text { Organizational } \\
\text { Performance }\end{array}$ & $\begin{array}{l}0.618 \\
0.497\end{array}$ & Accepted \\
\hline $\mathrm{H} 4$ & $\begin{array}{l}\text { Human } \\
\text { Capital }\end{array}$ & Innovation & $\begin{array}{c}\text { Organizational } \\
\text { Performance }\end{array}$ & $\begin{array}{l}0.214 \\
0.138\end{array}$ & Accepted \\
\hline
\end{tabular}

\section{DISCUSSION}

In today's dynamic environment, human capital and HRM practices both are very vital for the success of every organization. Human capital has the ability to bring innovation and renewal of strategies in the organization. The skills, knowledge and competencies possessed by the employees help the organizations in creating innovative goods and services due to which the complete productivity and performance of the organization is enhanced.

The findings of this research present that there is positive relationship between the human capital and Organizational performance. There has also been found positive and significant relationship between the HRM practices and performance.

These findings are in agreement with the other researcher results like (Youndtet al., 1996; Carmeli\&Tishler, 2004; Hsu, 2008; Colombo \&Grilli, 2009; Marimuthuet al., 2009; Choudhury, 2010). The results of this research is also consistent with a research in which the findings were found that having the capability of human capital the organization is able to create entrepreneurship behavior and improve the organizational performance (Barney, 2001).

The findings of this research also similar with the results of another research, in which the authors presented that with human capital the employees can obtain the skills of entrepreneur like expertise in managing resources strategically, develop creativity and agility (Alvarez \& Barney, 2002). These results are also in consistent with another research in which the findings 
are that there is positive relationship between human capital indicators and organizational performance (Seleim, Ashour\&Bontis, 2007; Maditinoset al., 2011).

\section{CONCLUSION}

The main aim of this study was to investigate the relationship between the human capital, HRM practices and organizational performance and also to analyze the mediating role of innovation in their relationship in the construction industry in Pakistan. Both human capital and HRM practices are the success factors for bringing increment in the performance of the organization.

The findings of the research presented that human capital, HRM practices, innovation and organizational performances are positively connected with each other. The organizational performance can be enhanced with creating an environment in the organization in which human capital of employees is improved and HRM practices are well implemented in construction organizations in Pakistan. The proposed structural model expressed that there will be improvement in the performance of the overall organization by implementing good training programs, effective performance appraisal system and with effective and efficient compensation system and with human capital.

The questionnaires sent to the employees of the construction sector organizations were 470 out of which 300 questionnaires were returned. The medium of sending questionnaires were emails. The emails addresses were taken from the management after introducing the purpose of the study and the importance of the research for the construction organizations. The response rate of the study was 63 percent which is considered as reasonable.

The construction organizations need to be effective and efficient in implementation of developing human capital and applying best policies of HRM practices in order to gain maximum benefits and increase the performance of the organization.

\section{RECOMMENDATIONS}

The main contributions of this study to the construction organizations are that the management should critically think about HRM practices and they should develop their employees by transferring the skills of entrepreneurship, knowledge and competencies in order to make them creative and innovative. These creative and innovative ideas will improve the performance of the organizations and ultimately the organizations will gain higher success rates.

There were many difficulties and obstacles due to the previous work done on this topic and the hesitance of the employees in these construction organizations to fill the questionnaires. There was also lack of research culture in the academics.

1. The first limitation of the study was that the sample used in this research was too small, it is suggested that in the future there should be large sample size taken to conduct research on this topic.

2. Another limitation is that the number of females working in construction organizations is also so short due to which it becomes very hard to generalize the findings of this research.

3. The third limitation is that the factors taken in HRM practices are only three, therefore, the future research should be based on some new variables too in order to broader the concept. 


\section{References}

1. Absar, M. M. N., \&Mahmood, M. (2011). New HRM practices in the public and private sector industrial enterprises of Bangladesh: A comparative assessment. International Review of Business Research Papers, $7(2), 118-136$.

2. Alvarez, S. A., \& Barney, J. B. (2002). Resource-Based Theory and the Entrepreneurial Firm,[w:] Strategic entrepreneurship. Creating a New Mindset, red.MA Hitt, RD Ireland, SM Camp, \& DL Sexton.

3. Anderson, J. C., \&Gerbing, D. W. (1988). Structural equation modeling in practice: A review and recommended two-step approach. Psychological bulletin, 103(3), 411.

4. Autio, E. (2005). Global Entrepreneurship Monitor (Gem)-2005 Report on High-Expectation Entrepreneurship. University of Illinois at Urbana-Champaign's Academy for Entrepreneurial Leadership Historical Research Reference in Entrepreneurship.

5. Barczak, G., \&Wilemon, D. (1992).Successful new product team leaders. Industrial Marketing Management, 21(1), 61-68.

6. Becker, B. E., Huselid, M. A., Pickus, P. S., \& Spratt, M. F. (1997). HR as a source of shareholder value: Research and recommendations. Human resource management, 36(1), 39-47.

7. Beer, M. S., Lawrence, B., \& Mills, P. Q. D. and Walton, R.(1984), Managing human assets.

8. Bosma, N., Van Praag, M., Thurik, R., \& De Wit, G. (2004).The value of human and social capital investments for the business performance of startups. Small Business Economics, 23(3), 227-236.

9. Buller, P. F., \&McEvoy, G. M. (2012). Strategy, human resource management and performance: Sharpening line of sight. Human resource management review, 22(1), 43-56.

10. Camisón, C., \&Villar-López, A. (2014).Organizational innovation as an enabler of technologicalinnovation capabilities and firm performance.Journal of Business Research, 67(1), 2891-2902

11. Carmeli, A., \&Tishler, A. (2004).The relationships between intangible organizational elements and organizational performance. Strategic management journal, 25(13), 1257-1278.

12. Choudhury, J. (2010). Performance Impact of Intellectual Capital: A Study of Indian it Sector. International Journal of Business and Management, 5(9), 72-80.

13. Colombo, M., \&Grilli, L. (2009). On growth drivers of high-tech start-ups: Exploring the role of founders' human capital and venture capital. Journal of business venturing, 25(6), 610-626.

14. Crespi, G., \& Zuniga, P. (2011). Innovation and Productivity: Evidence from Six Latin AmericanCountries. World Development, 40(2), 273-290. doi:10.1016/j.worlddev.2011.07.010

15. Dakhli, M., \& De Clercq, D. (2004). Human capital, social capital, and innovation: a multi-countrystudy. Entrepreneurship \& Regional Development, 16(2), 107-128.doi:10.1080/08985620410001677835

16. Edvinsson, L. Malone, (1997): Intellectual Capital. New York.

17. F. Hair Jr, J., Sarstedt, M., Hopkins, L., \& G. Kuppelwieser, V. (2014). Partial least squares structural equation modeling (PLS-SEM) An emerging tool in business research. European Business Review, 26(2), 106-121.

18. Florin, J., Lubatkin, M., \& Schulze, W. (2003).A social capital model of high-growth ventures. Academy of Management Journal, 46(3), 374-384.

19. Frese, M. (2000). STUDY DESIGN. Success and Failure of Microbusiness Owners in Africa: A Psychological Approach, 149.

20. Hair, J. F., Ringle, C. M., \&Sarstedt, M. (2011). PLS-SEM: Indeed a silver bullet. Journal of Marketing theory and Practice, 19(2), 139-152.

21. Harel, G. H., \&Tzafrir, S. S. (1999). The effect of human resource management practices on the perceptions of organizational and market performance of the firm. Human resource management, 38(3), 185-199.

22. Holmqvist, M. (2004).Experiential Learning Processes of Exploitation and Exploration. An EmpiricalStudy of Product Development, Organization Science 15(1): 70-81. 
23. Honig, B. (2001). Human capital and structural upheaval: A study of manufacturing firms in the West Bank. Journal of Business Venturing, 16(6), 575-594.

24. Hsu, I. (2008). Knowledge sharing practices as a facilitating factor for improving organizational performance through human capital: A preliminary test. Expert Systems with Applications, 35(3), 13161326.

25. Ishikawa, M., \& Ryan, D. (2002).Schooling, basic skills and economic outcomes. Economics of Education Review, 21(3), 231-243.

26. Jiménez-Jiménez, D., \&Sanz-Valle, R. (2011).Innovation, organizational learning and performance.Journal of Business Research, 64(4), 408-417.

27. Khatri, N. (2000). Managing human resource for competitive advantage: a study of companies in Singapore. International Journal of Human Resource Management, 11(2), 336-365.

28. Lau, R. S., \& May, B. E. (1998). A win-win paradigm for quality of work life and business performance. Human Resource Development Quarterly, 9(3), 211-226.

29. Lee, K., \& Kang, S.-M. (2007). Innovation Types and Productivity Growth: Evidence from KoreanManufacturing Firms. Global Economic Review, 36(4), 343359.doi:10.1080/12265080701694512

30. Maditinos, D., Chatzoudes, D., Tsairidis, C., \&Theriou, G. (2011).The impact of intellectual capital on firms' market value and financial performance.Journal of Intellectual Capital, 12(1), 132-151.

31. Marimuthu, M., Arokiasamy, L., \& Ismail, M. (2009). Human Capital Development and Its Impact on Firm Performance: Evidence from Developmental Economics. Journal of International Social Research, 2(8), 265-272

32. Moyeen, A. and Huq, A. (2001). Human resource management practices in business enterprises in Bangladesh, Journal of Business Studies, 22(2), 263-270.

33. Pfeffer, J. (1995), RekabetteÜstünlüğünSırrı: İnsan, çev: SinemGül, 2. Baskı, Sabah Yayınları, İstanbul.

34. Robson, P. J. a., Haugh, H. M., \&Obeng, B. A. (2009). Entrepreneurship and innovation in Ghana: enterprising Africa. Small Business Economics, 32(3), 331-350. doi:10.1007/s11187-008-9121-2

35. Schuler, R. S., \& Jackson, S. E. (1987).Linking competitive strategies with human resource management practices. The Academy of Management Executive (1987-1989), 207-219.

36. Schultz, T.W. (1993). The economic importance of human capital in modernization.Education Economics, 1(1), 13-19.

37. Seleim, A., Ashour, A., \&Bontis, N. (2007). Human capital and organizational performance: a study of Egyptian software companies. Management Decision, 45(4), 789-801.

38. Smith, K. G., Collins, C. J., \& Clark, K. D. (2005).Existing Knowledge, Knowledge CreationCapability, and the Rate of New Product Introduction in High-Technology Firms.Academy ofManagement Journal, 48(2), 346-357.doi:10.5465/AMJ.2005.16928421

39. Sonnentag, S. (2002). Psychological Management of Individual Performance: A Handbook in the Psychology of Management in Organizations. John Wiley \& Sons Inc. (pp. 3-25).

40. Tampoe, M., \&Thurloway, L. (1993). Project management: the use and abuse of techniques and teams (reflections from a motivation and environment study). International Journal of Project Management, $11(4), 245-250$.

41. Tan, C. L. and Nasurdin, A. M. (2010), Human resource management practices and organizational innovation: An empirical study in Malaysia\|, Journal of Applied Business Research, 2(4), 105-115.

42. Werther, W. and Davis, K. (1996).Human resources and personnel management.New York: McGraw-Hill, Inc.

43. Wright, P. M., Dunford, B. B., \& Snell, S. A. (2001). Human resources and the resource based view of the firm. Journal of Management, 27(6), 701-721. http://dx.doi.org/10.1177/014920630102700607 
Sarwar, H., Khan, B., Nnadeem, K. \& Aftab, J. (2016). Human Capital, HRM Practices and Organizational Performance in Pakistani Construction Organizations: the Mediating Role of Innovation. Archives of Business Research, 4(6), 72-82.

44. Youndt, M., Snell, S., Dean, J., \&Lepak, D. (1996). Human resource management, manufacturing strategy, and firm performance.Academy of Management Journal, 39(4), 836-866.

45. Yu, B. B., \&Egri, C. P. (2005). Human resource management practices and affective organizational commitment: A comparison of Chinese employees in a state-owned enterprise and a joint venture. Asia Pacific Journal of Human Resources, 43(3), 332-360. 